Article

\title{
Towards Nearly Zero Energy and Environmentally Sustainable Agritourisms: The Effectiveness of the Application of the European Ecolabel Brand
}

\author{
Laura Cirrincione $^{1, * \mathbb{D}}$, Maria La Gennusa ${ }^{1} \mathbb{D}$, Giorgia Peri $^{1}$, Gianfranco Rizzo ${ }^{1}$ and \\ Gianluca Scaccianoce ${ }^{1,2}$ \\ 1 Department of Engineering, University of Palermo, Viale delle Scienze Bld. 9, 90128 Palermo, Italy; \\ maria.lagennusa@unipa.it (M.L.G.); giorgia.peri@unipa.it (G.P.); gianfranco.rizzo@unipa.it (G.R.); \\ gianluca.scaccianoce@unipa.it (G.S.) \\ 2 National Research Council of Italy, Institute of Biomedicine and Molecular Immunology, \\ via Ugo La Malfa 153, 90146 Palermo, Italy \\ * Correspondence: laura.cirrincione@unipa.it
}

Received: 28 July 2020; Accepted: 17 August 2020; Published: 19 August 2020

\begin{abstract}
Tourism represents an important economic driver in Italy, being responsible for approximately $13.2 \%$ of the total GDP (a value higher than the reference European average) and for nearly $10 \%$ of the regional GDP. Among the touristic sectors, the agritourist ones show a persistent growth, experiencing in 2019 a 6.7 point percentage improvement compared to the 2017 figures. Given this situation, the transition towards a low-carbon path, affecting the building sector for some time, should also involve agritourist buildings, through the release of EU directives, member state laws, and technical rules. On the other hand, agritourism sites could be awarded the Community EU Ecolabel. Unfortunately, awarding the EU environmental excellence brand implies the availability of several data on building energy behavior that should then be managed by complex evaluation tools. To overcome this issue, the use of the simplified ARERA (Italian Regulatory Authority for Energy Networks and Environment) technical datasheets, issued to assess environmental improvements consequent to energy efficiency interventions in the urban residential building stock, is proposed. The application of this tool totally avoids using building computer-based simulation models, thus facilitating the preparation of the EU Ecolabel request documentation by agritourism owners. Being awarded the Community EU Ecolabel also implies approaching a net zero energy condition because of a lower energy consumption and a minor recourse to fossil fuels. For this purpose, an application of an easy graphical method, previously developed for residential and commercial buildings, which visually represents improvements achievable by a given agritourism when implementing energy efficiency measures, is presented.
\end{abstract}

Keywords: building energy efficiency; European environmental brands; tourism sector; agritourism; nearly zero energy buildings (nZEB)

\section{Introduction}

Tourism, and the activities connected to it, represent an important sector of the economic system. According to recent statistics the tourism industry represents about $10 \%$ of total global gross domestic product (GDP) and 7\% of global trade [1,2], accounting for approximately 11\% of the world's employment, with an expected positive economic growth trend $[3,4]$. Tourism constitutes a significant contributor to energy consumption, both at a global and European scale [5-7], which translates to a significant impact on the environment and ecosystem; it is in fact responsible for about $5 \%$ of the global $\mathrm{CO}_{2}$ emitted by human activities $[1,8]$. 
Accommodation (thus the building), in particular, is the third energy consuming item (after travel and transport), much of which is consumed in space heating or air conditioning (up to $50 \%$ in some cases), followed by hot water, and cooking [9,10]. Moreover, a study conducted by the World Tourism Organization and the United Nations Environment Programme [11] estimates that accommodation generates $21 \%$ of tourism's total greenhouse gas (GHG) emissions. Accordingly, the number of papers analyzing tourism significance, in terms of energy consumption $[12,13]$ and impacts on emissions [14,15], has been increasing lately.

Consequently, in recent years much attention has been paid to the concept of sustainable tourism, which in accordance with the United Nations Environment Programme (UNEP) and the United Nations World Tourism Organization (UNTWO) is defined as "development of tourism activities with a suitable balance between the dimensions of environmental, economic, and sociocultural aspects to guarantee its long-term sustainability". Hence, the challenge of sustainable tourism is to mitigate its negative impacts, consisting mainly in: (i) high energy consumption, (ii) increasing GHG emissions in the atmosphere, and (iii) the contribution to climate change [16].

Therefore, taking into consideration global [17,18], European [19-22], and national [23] policies, the UNWTO recommended three central actions on which the tourism sector should concentrate in order to contribute in achieving a more sustainable development [1,24], which are resource efficiency, environmental protection, and climate change (linked to sustainable development goals (SDGs) 6, 7, 8, $11,12,13,14$, and 15) [25].

At the European scale, the European Commission set the basis for the best environmental management practice in the tourism sector in accordance with Article 46 of the Eco-Management and Audit Scheme (EMAS) regulation [26,27]. Furthermore, by means of the "Guide on EU funding for the tourism sector 2014-2020" [28] the EU states that effective governance, policies, frameworks, and tools need to be implemented in order to properly guide and support (also from an economic point of view) the development and promotion of sustainable tourism practices.

Tools like these are indeed important because they encourage the owners and/or managers of the accommodation facilities to use practices and systems that allow both energy savings and pollutant emissions, by favoring the visibility of these structures in terms of environmental sustainability, which represent an added value, given that tourists are becoming increasingly more attentive to this issue.

In this regard one of the first initiatives undertaken by the European Community has been the releasing of the EU Ecolabel for tourist accommodation services [29], created to improve the environmental performance of hotels, campsites, hostels, agritourisms, holiday homes, and bed \& breakfasts, by providing efficient guidelines on the action to be implemented in order to lower their environmental impact; and which still remains one of the most implemented initiatives.

The promotion of sustainable tourism is also the basis of the nearly zero-energy hotels (neZEH) project, launched by the Intelligent Energy Europe Programme of the European Commission, with the intent of supporting European hotels in complying with the nZEB (nearly-Zero Energy Buildings) regulations [1]. On this subject, various studies have been conducted aimed at analyzing the achievable energy saving measures [30-32] and proposing suitable strategies and policies to be adopted [33,34].

Looking at the national scenario, the tourism issue is particularly relevant, considering that $16.5 \%$ of EU accommodation facilities are located in Italy [35], and since in the last two years Italy resulted to be amongst the top five most visited European tourist destinations (for accommodation in hospitality facilities), with a $13.4 \%$ share of the total of the EU-28 [36,37].

According to some recent statistics, the Italian tourism sector represents $13.2 \%$ of the national GDP (for a total contribution of around 230 billion euros), higher than both the world and European figures (which stand at around 10\%). The economic impact of tourism is significantly reflected in the job market, accounting for $14.9 \%$ of the country's total employment [38]. Tourism is in fact one of the fastest growing industrys in Italy, and both public and private business organizations are strongly interested in its economic and environmental impact, both at national and regional level $[39,40]$. 
Thus, from the collaboration between such organizations and the national and regional governments, different initiatives have been undertaken from an environmental sustainability point of view in recent years. These include the creation of a set of national environmental quality certifications (besides the previously cited EU Ecolabel), including the "Green Key" [41], "Bandiera Blu" [42], and "Spighe Verdi" [43], born from the collaboration between the Italian Foundation for Environmental Education-FEE Italia (whose actions are supported by ONU, UNEP, UNWTO, and UNESCO) and national authorities dealing with environmental policies [44].

Furthermore, other economic initiatives have been implemented to encourage the use of sustainable energy solutions through financial incentives. The "Tax Credit Alberghi-Bonus alberghi e agriturismi" (bonus for hotels and agritourism), a tax facility that encourages various upgrading activities, including those aimed at improving energy efficiency, has recently been introduced, specifically for accommodation facilities [45].

Agritourism, or rural tourism, has been promoted as a practice able to encourage the use of green practices, making farms sustainable and also maintaining the local historical and natural settings $[8,46]$.

Thanks to this, according to recent statistics in Italy, the agritourism sector continues to record a growing trend, both in the number of structures, and in the presence of customers and its economic value. Agriculture economic reports make it possible to measure the economic dimension of the agritourism sector, which is equal to 1.36 billion euros, up $6.7 \%$ compared to the previous year. In particular, $60 \%$ of agritourisms are located in the regions of central and southern Italy, where Sicily prevails with more than 600 farms [47].

The growing interest in the agritourism sector is also reflected in the academic world, where studies concerning both the economic and social benefits of various tourist activities in the rural area, including agritourism [48], and the environmental performance of agritourism companies in terms of energy performance $[49,50]$, can be found.

In the present work we verified whether the simplified ARERA (Italian Regulatory Authority for Energy Networks and Environment) technical datasheets [51], issued for the urban residential building stock, can be easily applied to estimate the increase in energy efficiency (or the corresponding decrease in the release of polluting substances) consequent to the adoption of some improvements to a building or plant, planned for the issuance of the EU Ecolabel brand for accommodation facilities [29]. The convenience in the use of these technical datasheets lies in the fact that they allow the estimation of the energy demand reductions without necessarily going through the building simulation. For this purpose, a case study has been conducted to estimate what advantages agritourism owners could gain in adopting a well-known brand such as the EU Ecolabel [29], with particular reference to the actions aimed at saving energy and reducing emissions of pollutants, from the perspective of a possible "nearly Zero Energy Agritourism (nZEA)", in parallel with the previously cited nZEB and neZEH projects.

The idea at the base of this work stems from the numerical consistency of agritourisms in Sicily [47] and their conceivable growth trend, which is a consequence of the increased interest in the rural landscape of the territory and in the products of the land that are strongly orienting tourism, directing it not only towards the urban context. The adoption of an environmental certificate like the EU Ecolabel [29] can therefore represent an advantage both for agritourism owners and for the entire territory.

Furthermore, the owners of agritourism in Sicily can apply for subsidized loans and financial funding $[28,52]$ in the regional area and beyond. However, such requests must be supported by information concerning the consumption and energy efficiency of the agritourism and, in line with the new European directives on sustainability [17-19], by information on the environmental performance of the buildings themselves (premises).

Normally this information is of a complex nature and tends to imply the use of sophisticated simulation models, the use of which is not always the prerogative of (or available to) the managers of the holiday farms. The same problem can be found by analyzing the work of the decision makers who have to assess the adequacy of the requests for funding. 
Essentially, the availability of simple but reliable tools for evaluating these premises is of paramount importance for the orientation of this important tourism sector towards a sustainable path.

Hence, as previously mentioned, in order to provide a contribution to this important issue we assessed the reliability of a scheme of simple computational methods provided by the Italian Regulatory Authority for Energy Networks and Environment-ARERA [51], specifically for the residential and tertiary building stock. The advantage in the use of this computational scheme lies indeed in the fact that it is based on excel spreadsheets (technical datasheets) which, as already mentioned, allow the estimation of the energy demand reductions without the need of simulating the building behavior.

\section{Materials and Methods}

The proposed methodology aims at considering together in an easy and accessible way two aspects of the sustainability, which are energy efficiency and environmental safety, in order to help agritourism owners, and/or managers, to make decisions that are more favorable to them and consistent with the European policies in force. Specifically, according to the presented approach, the selection of energy efficiency interventions is based on a combination of the ARERA technical datasheets and the EU Ecolabel criteria, hence taking into account the environmental sustainability aspects, and also in view of achieving a possible nearly zero energy condition (nZEA). Therefore, two Sicilian agritourisms have been selected to show how the application of the proposed methodology actually works.

The considered approach can also be seen as a simple diagnosis method aimed at facilitating the social appropriation of knowledge and technology, so that the owners of agritourism facilities can confidently check their level of eco-efficiency. Moreover, the method can be utilized in order to choose between addressing actions concerning the energy performance of the structure or interventions regarding the installation of new (renewable) energy plants.

\subsection{Agritourism Definition}

The Italian national legislation [53], and the regional Sicilian one [54,55], define as 'agritourism' activities, those reception and hospitality activities exercised by agricultural entrepreneurs, through the use of their own company connected with the activities of cultivation of the land, forestry, and animal breeding. Thus, agritourism activities include:

- providing accommodation;

- administering meals and beverages consisting mainly in products of their own production and products from farms in the local area;

- $\quad$ organizing recreational, cultural, educational, sports, and excursion activities aimed at promoting and supporting the territory and the rural heritage.

\subsection{The ARERA Technical Datasheets}

In the present work, the use of ARERA technical datasheets [51] was not an arbitrary (random) choice, but it was decided to turn to these methods since, although simplified, they constitute an official reference at the Italian national level.

The Italian Regulatory Authority for Energy Networks and Environment-ARERA is indeed an independent body, established with the task of protecting consumers' interests and promoting competition, efficiency, and the spread of services, and having adequate quality levels, through regulation and control activities. The action of ARERA concerns the sectors of electricity and natural gas [56], water services [57], district heating and district cooling [58], and the waste cycle [59].

One of the main tasks of ARERA is to promote the rational use of energy, with particular reference to the promotion and diffusion of end use energy efficiency and/or energy saving actions, and the adoption of measures for sustainable development. Among the feasible actions, there are both active measures, which involve the installation of high efficiency equipment, or the insertion of regulation 
devices for a more efficient use of energy, and passive interventions such as the modification of buildings' envelope in order to reduce losses.

In this regard, the technical datasheets proposed by ARERA establish the guidelines for the preparation, execution, and final evaluation of specific actions, aimed at increasing energy efficiency (or promoting energy saving), providing reduced rates of primary energy consumption actually achieved (expressed in toe-Tons of oil equivalent), and also for the purpose of issuing energy efficiency certificates. Table A1 in Appendix A reports a comprehensive list of the current standardized and analytical ARERA technical datasheets.

\subsection{The EU Ecolabel Brand}

Established in 1992 (by Regulation n. 880/92 [60], now disciplined by Regulation (EC) n. 66/2010 [61] in force in the EU-28) and recognized across Europe and worldwide (Figure 1), the EU Ecolabel is a voluntary environmental performance certificate that is awarded to products and services meeting high environmental standards. The EU Ecolabel encourages companies to develop products and provide services that consume less energy, and generate less waste and $\mathrm{CO}_{2}$ emissions. As of March 2019, an increase by $88 \%$, with respect to 2016, of the number of EU Ecolabelled products/services has been registered. Leading countries for number of products/services are: Spain, Italy, Germany, Belgium, and France [62].

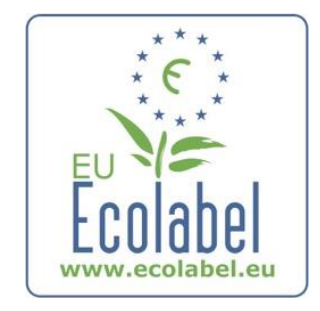

Figure 1. Official EU Ecolabel logo [62].

The EU Ecolabel provides exigent criteria, and relative guidelines, depending on the type of product and/or service, in order to reduce their overall environmental impact. Such criteria are established at a European scale with a wide participation of interested parties, including both public authorities, and consumer and environmental associations [63].

In particular, the EU Ecolabel for tourist accommodation services [29] was created specifically for hotels, campsites, hostels, agritourisms, holiday homes, and bed \& breakfasts, in order to improve their environmental performance, by providing a set of criteria on the action to be implemented in order to lower their impact. Such criteria are divided into mandatory and optional, and focus on the five categories; general management, energy, water, waste and wastewater, and other, as shown in Table A2 in Appendix A.

In order to be awarded the EU Ecolabel a tourist accommodation service, other than falling within the product group "tourist accommodation" according to the legal obligations of the country in which the accommodation is located, must comply with all the mandatory criteria (if applicable), and receive at least twenty points under the optional criteria [29].

An added value, in terms of visibility, for tourist accommodation owners lies in the fact that the EU Ecolabel is recognized by the majority of travelers as a way of legitimizing the accommodation's claims that it is making real efforts to reduce its impact on the environment in its operational activities.

\subsection{Analysis Methodology}

\subsubsection{Merging the ARERA Technical Datasheets and the EU Ecolabel Criteria}

As mentioned in the introduction section, the aim of the present work is to verify whether the simplified ARERA technical datasheets can be applied to estimate the increase in energy 
efficiency consequent to the adoption of some actions planned for the issuance of a EU Ecolabel for Tourist Accommodation Services, without necessarily going through the building simulation. Obviously, an increase in the energy efficiency implies a corresponding decrease in the release of polluting substances.

Therefore, since this work is mainly focused on the energy criteria, starting from the assumption that the considered agritourism meets all the mandatory criteria, it was decided to analyze possible "environmental action packages", consisting of different combinations of the actions established by the optional energy criteria, which are better suited to a scenario such as agritourism, and which allow the obtaining of the weight of the energy category on the twenty points minimum limit set by the regulation, which corresponds to 7.34 points.

To this purpose, only the ARERA datasheets regarding the actions related to the improvement of the structure energy efficiency that could be transferred and applied to agritourism structures, according to the EU Ecolabel for Tourist Accommodation energy criteria, have been considered, as reported in Table 1, where the correspondent energy consumption categories have also been reported.

Table 1. Correspondence between the Italian Regulatory Authority for Energy Networks and Environment (ARERA) datasheets and the EU Ecolabel energy criteria.

\begin{tabular}{cccc}
\hline $\begin{array}{c}\text { ARERA Technical } \\
\text { Data Sheet N. }\end{array}$ & $\begin{array}{c}\text { EU Ecolabel } \\
\text { Criterion N. }\end{array}$ & $\begin{array}{c}\text { EU Ecolabel } \\
\text { Achievable Points }\end{array}$ & $\begin{array}{c}\text { Energy Consumption } \\
\text { Category } \mathbf{1}\end{array}$ \\
\hline 5 & 33 & 4 & HVAC \\
7 & $39,40,41$ & 3.5 & RES \\
$8 \mathrm{~T}$ & 6 & 2 & DHW \\
$15 \mathrm{~T}$ & 6,7 & 1.5 & HVAC \\
$19 \mathrm{~T}$ & 7 & 3.5 & HVAC \\
$27 \mathrm{~T}$ & 6 & 1.5 & DHW \\
6 & - & - & HVAC \\
$20 \mathrm{~T}$ & - & - & \\
\hline
\end{tabular}

${ }^{1}$ HVAC—Heating, Ventilation, and Air Conditioning; DHW—Domestic Hot Water; RES-Renewable Energy Source.

As can be seen in Table 1, under the dotted line, the two ARERA datasheets 6T and 20T, additional to those that can be associated to the EU Ecolabel, have also been taken into account. In fact, even though these two intervention typologies are not foreseen by the current Ecolabel scheme, they represent actions that can actually be applied to an agritourism structure in the perspective of a possible "nearly Zero Energy Agritourism (nZEA)" as a parallel with the well-known nZEB concept; and also, in view of a possible future improvement of the Ecolabel scheme.

The selected datasheets (Table 1), have been then put into the form of appropriate excel spreadsheets.

The equations relative to the ARERA calculation procedures, for each considered technical datasheet, are given in Appendix B.

One aspect that must be highlighted here regards the fact that while datasheets 5, 6, 15T, 19T, 20T, and 27T enable obtaining savings of consumed energy (energy saving measures, ESM), datasheets 7 and $8 \mathrm{~T}$ allow, instead, the production of energy from renewable sources (renewable energy sources, RES).

\subsubsection{Methodology Application Feasibility}

With the aim of assessing the potential energy savings, with reference to a real context, it was decided to select two agritourisms situated in the Sicilian province of Palermo, considered as representative of the whole regional agritourism context regarding the size, the provided services, and more importantly for the purpose of the proposed methodology object of the present work, in terms of energy consumption. Apart from these physical and energy features, both agritourisms were selected thanks to their wide offer of services, which are representative of these kind of farms, and due to the fact that they operate in the two climatic zones where agritourisms are mainly sited in 
Sicily. Specifically, the two agritourism are Villa Dafne, sited in Alia and belonging to climatic zone D, and Bergi, located in Castelbuono and classified as climatic zone C. Both agritourisms fall into solar belt 3 . Table 2 describes the main general characteristics of the two structures.

Table 2. General characteristics of the two selected agritourisms.

\begin{tabular}{ccc}
\hline Characteristic & Villa Dafne & Bergi \\
\hline Covered surface $\left(\mathrm{m}^{2}\right)$ & 1000 & 1400 \\
Glazed surface $\left(\mathrm{m}^{2}\right)$ & 236 & 305 \\
Opaque surface $\left(\mathrm{m}^{2}\right)$ & 2768.5 & 2791.75 \\
Surface/Volume ratio $(-)$ & 0.62 & 0.5 \\
N. of seats in the dining area & 150 & 180 \\
N. of rooms & 35 & 34 \\
\hline
\end{tabular}

In Table 3 is reported the information relative to the energy characteristics of interest for the conducted study, which were obtained by on field surveys and interviews with the owners of the two businesses, thanks to which it was possible to reconstruct the energy consumption relative to an entire year of operation of the structures. In particular, the data regarding the energy consumption were distributed between four main categories and accordingly broken down into percentages, and corresponding toe/year, also with reference to the corresponding energy sources. As for the energy sources' average costs, the following values were used:

- $\quad 0.19 € / \mathrm{kWh}$ for electricity;

- $\quad 1.17 € / \mathrm{Sm}^{3}$ for natural gas;

- $\quad 0.90 € /$ lt. for diesel oil.

Table 3. Energy sources and energy consumption breakdown for the two selected agritourisms.

\begin{tabular}{cccccc}
\hline \multirow{2}{*}{ Category } & Source & \multicolumn{2}{c}{ Villa Dafne } & \multicolumn{2}{c}{ Bergi } \\
\cline { 2 - 5 } & natural & $\%$ & Toe/Year & $\%$ & Toe/Year \\
\hline $\begin{array}{c}\text { Domestic Hot Water } \\
\text { (DHW) }\end{array}$ & \begin{tabular}{c} 
gas/diesel oil \\
\cline { 2 - 5 }
\end{tabular} & 0 & 0.00 & 16 & 5.09 \\
\hline electricity & 22 & 9.72 & 6 & 1.91 \\
\hline $\begin{array}{c}\text { Lighting } \\
\text { Heating, Ventilation and } \\
\text { Air Conditioning } \\
\text { (HVAC) }\end{array}$ & $\begin{array}{c}\text { electricity } \\
\text { gas/diesel oil }\end{array}$ & 15 & 6.63 & 15 & 4.77 \\
\cline { 2 - 5 } & electricity & 14 & 11.05 & 15 & 4.77 \\
\hline Other & $\begin{array}{c}\text { natural } \\
\text { gas/diesel oil }\end{array}$ & 0 & 6.19 & 24 & 7.64 \\
\cline { 2 - 5 } & electricity & 24 & 10.60 & 0 & 0.00 \\
\hline & Total & 44.18 & 24 & 7.64 \\
\hline
\end{tabular}

Subsequently, it was hence possible to obtain the achievable energy savings (AES), in terms of percentage of electricity consumption covered by the datasheets proposed interventions on an annual basis, by comparing the values obtained from Equations (A1) to (A8), and the total energy consumption (Table 3), by means of the following equation:

$$
A E S_{i}=\frac{R_{i}}{\text { Tot. cons. } j}[\%]
$$

where: 
- $\quad R_{i}$ represent the energy savings obtained from Equations (A1) to (A8);

- $\quad$ Tot. cons.j is the total figure reported in Table 3;

- $\quad i$ and $j$ represent the selected intervention and the considered agritourism, respectively.

Regarding the pollutant emissions, an assessment of the $\mathrm{CO}_{2}$ emissions' reduction was conducted assuming for the considered climatic context an emission factor equal to $2.30 \mathrm{tCO}_{2} \mathrm{eq} /$ toe for the electrical supply $[64,65]$, while for natural gas and diesel oil an emission factor of $3.08 \mathrm{tCO}_{2} \mathrm{eq} /$ toe and $2.34 \mathrm{tCO}_{2} \mathrm{eq} /$ toe, respectively [66].

In order to single out the most convenient aforementioned "environmental actions packages", an economic estimation relative to the interventions suggested by the ARERA technical datasheets was also performed. To this purpose, the information relative to the costs of supply and installation for the materials, used to calculate the proposed interventions costs, were obtained from the current regional price list [67] and from local market surveys, as reported in Table 4.

Table 4. ARERA technical datasheets proposed interventions costs.

\begin{tabular}{|c|c|c|}
\hline Datasheet $\mathbf{N}^{\circ}$ & Proposed Intervention & Cost \\
\hline 5 & Replacement of simple glazing with double glazing & $407.13 € / \mathrm{m}^{2}$ \\
\hline 7 & $\begin{array}{l}\text { Use of photovoltaic systems with an electrical power } \\
\text { of less than } 20 \mathrm{~kW}\end{array}$ & $1898.42 € / \mathrm{kW}_{\mathrm{p}}$ \\
\hline $8 \mathrm{~T}$ & $\begin{array}{l}\text { Installation of solar collectors for the production of } \\
\text { domestic hot water }\end{array}$ & $578.73 € / \mathrm{m}^{2}$ \\
\hline $15 \mathrm{~T}$ & $\begin{array}{l}\text { Installation of outdoor air electric heat pumps } \\
\text { instead of boilers in newly built or renovated } \\
\text { residential buildings }\end{array}$ & $4901.323 € /$ UFR * \\
\hline $19 \mathrm{~T}$ & $\begin{array}{l}\text { Installation of high efficiency outdoor air } \\
\text { conditioners with cooling capacity lower than } 12 \mathrm{~kW}_{\mathrm{f}}\end{array}$ & $490.13 € / \mathrm{kW}$ \\
\hline $27 \mathrm{~T}$ & $\begin{array}{l}\text { Installation of electric heat pump for domestic hot } \\
\text { water production in new and existing plants }\end{array}$ & $570.65 € / \mathrm{UFR} *$ \\
\hline 6 & Wall and roof insulation & $29.32 € / \mathrm{m}^{2}$ \\
\hline $20 \mathrm{~T}$ & $\begin{array}{l}\text { Thermal insulation of walls and roofs for summer } \\
\text { cooling in domestic and service sectors }\end{array}$ & $29.32 € / \mathrm{m}^{2}$ \\
\hline
\end{tabular}

Successively, the economic savings, in terms of saved $€$ /year, were obtained by multiplying the energy savings with the energy sources' average costs, according to the considered categories breakdown (Table 1). Furthermore, in order to select the optimal "environmental actions packages", for these the pay-back periods (not discounted) were also calculated and expressed in years.

\section{Results}

In this section the outcomes of the application of analysis methodology are reported.

Regarding the input parameters used in the equations relative to the ARERA calculation procedures, for each considered technical datasheets, these are given in Table A3 in Appendix B.

The following Figures 2 and 3 show the achievable energy savings (AES) on the total annual consumption, relative to the application of the intervention proposed by each considered ARERA datasheet, to the two agritourisms. On the right side of the graphs, the EU Ecolabel points corresponding to each datasheet are also reported. 
Villa Dafne agritourism' achievable energy savings for each datasheet

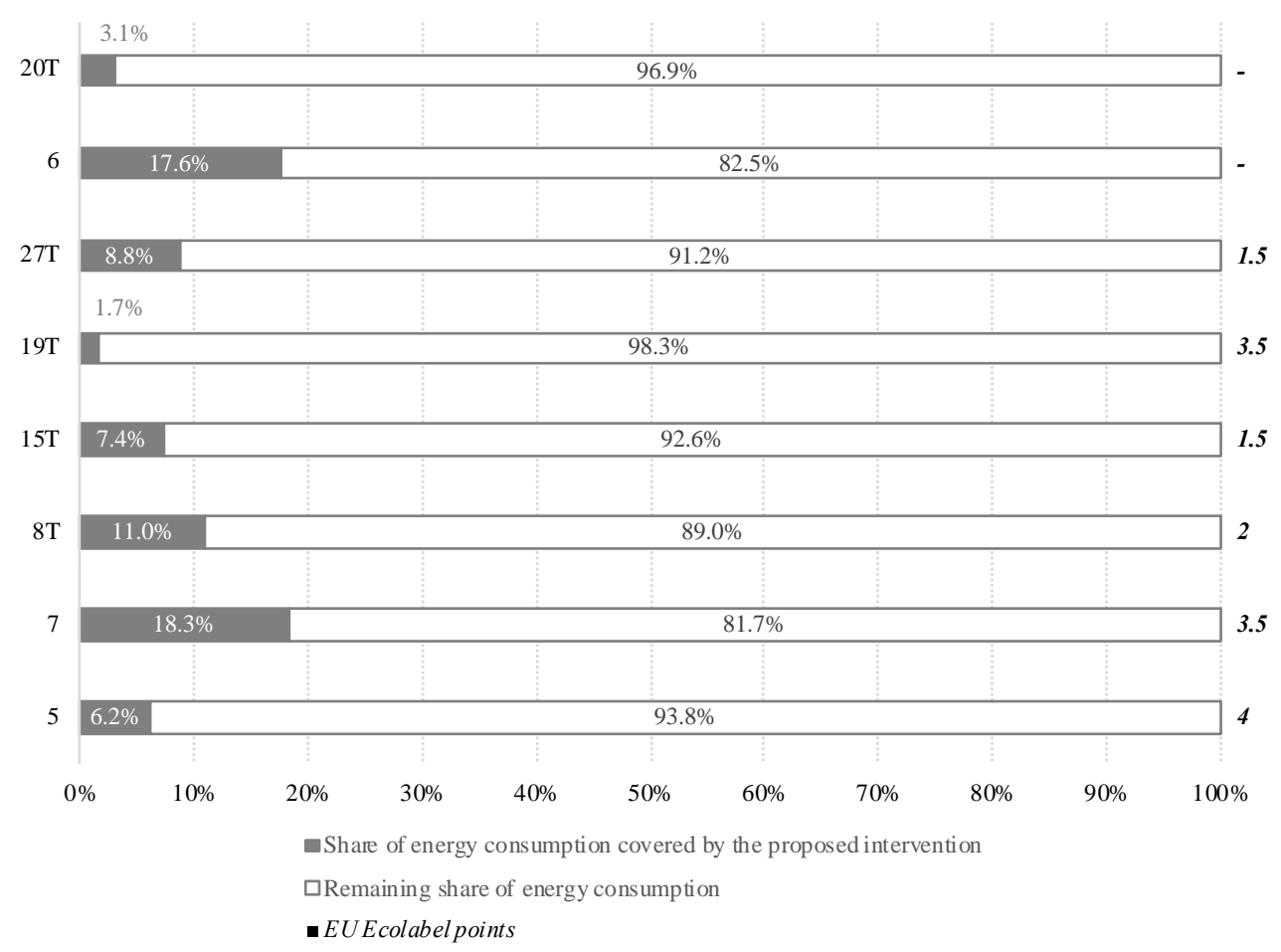

Figure 2. Achievable energy savings (AES), on an annual basis, and EU Ecolabel points relative to each considered ARERA datasheet for Villa Dafne agritourism.

Bergi agritourism' achievable energy savings for each datasheet

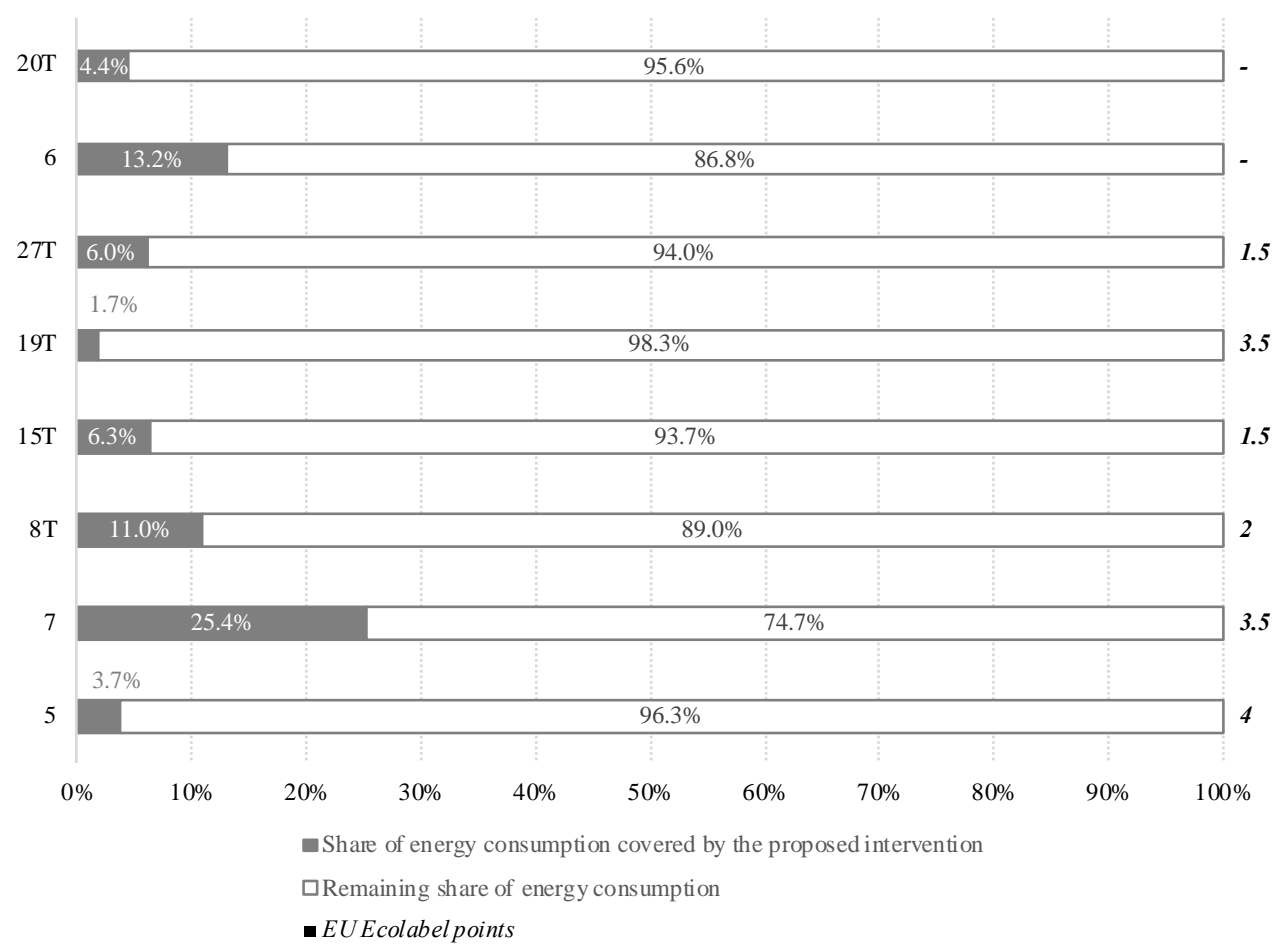

Figure 3. Achievable energy savings (AES), on an annual basis, and EU Ecolabel points relative to each considered ARERA datasheet for Bergi agritourism. 
Figures 2 and 3 show how, amongst the ARERA proposed interventions enabling the obtaining of an EU Ecolabel score, the implementation of a photovoltaic (PV) system (datasheet 7) would be the one allowing the gain of a greater advantage in terms of energy consumption. Concerning the savings related to the domestic hot water (DHW) category, by comparing datasheets $8 \mathrm{~T}$ and $27 \mathrm{~T}$, which are alternatives to each other, it can be observed how $8 \mathrm{~T}$ would be the more convenient choice. Regarding the heating, ventilation, and air conditioning (HVAC) category, the savings achievable through the application of datasheets $15 \mathrm{~T}$ and $19 \mathrm{~T}$ should, instead, be considered jointly $(15 \mathrm{~T}+19 \mathrm{~T})$ as they can be attributed to the same improvement intervention. As for datasheet 5, although it represents one of the easiest measures to implement, it does not seem to bring the benefits that would have been expected.

With respect to datasheets 6 and 20T, also in this case the consideration that the attainable benefits must be considered together $(6+20 \mathrm{~T})$ is valid. As already explained these two datasheets fall out of the Ecolabel scoring scheme, nevertheless they represent the second-best intervention that allows the highest energy savings, after datasheet 7 .

The overall obtained results for the two considered agritourisms are reported in Tables 5 and 6.

Table 5. Proposed interventions costs and environmental benefits for Villa Dafne agritourism.

\begin{tabular}{cccccc}
\hline $\begin{array}{c}\text { ARERA } \\
\text { Datasheet N. }\end{array}$ & $\begin{array}{c}\text { EU Ecolabel } \\
\text { Points }\end{array}$ & $\begin{array}{c}\text { Proposed } \\
\text { Intervention } \\
\text { Cost (€) }\end{array}$ & $\begin{array}{c}\text { Energy } \\
\text { Savings (AES) }\end{array}$ & $\begin{array}{c}\mathbf{C O}_{2} \text { Emissions } \\
\text { Reduction } \\
\text { (tCO } \mathbf{2} \text { eq/Year) }\end{array}$ & $\begin{array}{c}\text { Economic } \\
\text { Savings } \\
\text { (€/Year) }\end{array}$ \\
\hline 5 & 4 & $123,971.09$ & $6.20 \%$ & 7.7 & 2831.21 \\
7 & 3.5 & $37,588.70$ & $18.26 \%$ & 18.6 & 8053.63 \\
$8 \mathrm{~T}$ & 2 & $13,392.91$ & $11.00 \%$ & 11.2 & 4851.56 \\
$15 \mathrm{~T}$ & 1.5 & $98,026.40$ & $7.37 \%$ & 10.0 & 3429.31 \\
$19 \mathrm{~T}$ & 3.5 & $1.67 \%$ & 1.7 & 738.75 \\
$27 \mathrm{~T}$ & 1.5 & $20,930.15$ & $8.80 \%$ & 9.0 & 3881.25 \\
6 & - & $81,172.42$ & $17.55 \%$ & 23.9 & 738.74 \\
$20 \mathrm{~T}$ & - & & $3.13 \%$ & 3.2 & 1381.90 \\
\hline
\end{tabular}

Table 6. Proposed interventions costs and environmental benefits for Bergi agritourism.

\begin{tabular}{cccccc}
\hline $\begin{array}{c}\text { ARERA } \\
\text { Datasheet N. }\end{array}$ & $\begin{array}{c}\text { EU Ecolabel } \\
\text { Points }\end{array}$ & $\begin{array}{c}\text { Proposed } \\
\text { Intervention } \\
\text { Cost }(\boldsymbol{\epsilon})\end{array}$ & $\begin{array}{c}\text { Energy } \\
\text { Savings (AES) }\end{array}$ & $\begin{array}{c}\mathbf{C O}_{2} \text { Emissions } \\
\text { Reduction } \\
\text { (tCO } \mathbf{2} \text { eq/Year) }\end{array}$ & $\begin{array}{c}\text { Economic } \\
\text { Savings } \\
(\boldsymbol{\epsilon} / \text { Year) }\end{array}$ \\
\hline 5 & 4 & $95,980.90$ & $3.70 \%$ & 2.73 & 1350.79 \\
7 & 3.5 & $37,588.70$ & $25.35 \%$ & 18.59 & 8053.63 \\
$8 \mathrm{~T}$ & 2 & $14,608.10$ & $11.00 \%$ & 8.18 & 4595.95 \\
$15 \mathrm{~T}$ & 1.5 & $73,519.80$ & $6.29 \%$ & 4.69 & 2767.13 \\
$19 \mathrm{~T}$ & 3.5 & $1.74 \%$ & 1.28 & 554.06 \\
$27 \mathrm{~T}$ & 1.5 & $10,182.10$ & $6.00 \%$ & 4.40 & 1905.96 \\
6 & - & $81,854.11$ & $13.16 \%$ & 9.81 & 1212.67 \\
$20 \mathrm{~T}$ & - & & $4.39 \%$ & 3.22 & 1393.51 \\
\hline
\end{tabular}

As can be observed, according to what has been previously pointed out, a single intervention cost was given to datasheets $15 \mathrm{~T}$ and $19 \mathrm{~T}$ as the proposed intervention corresponds to the same type of system, i.e., the same system allows operation for both heating and cooling. The same consideration can be made for datasheets 6 and 20T in relation to the insulation of the building.

Looking at the economic savings column it can be noticed how, from this point of view greater advantages can be associated with datasheets 7 and $8 \mathrm{~T}$, followed by $15 \mathrm{~T}+19 \mathrm{~T}, 27 \mathrm{~T}$ and lastly 5 . Considering the whole set of interventions, instead, the $(6+20 \mathrm{~T})$ option would also result second in this case.

Referring to $\mathrm{CO}_{2}$ emissions reduction, the obtained results are obviously in line with what was seen beforehand (Figures 2 and 3 ) and commented on with the energy savings. 


\section{Discussion}

The application of the ARERA data sheets to agritourism raises a question concerning the suitability of these simplified forms to the energy performances of agritourisms sites, being originally developed for residential and commercial buildings.

On the other hand, a possible improvement of the energy features of an agritourism, due to the actions referred to in the ARERA datasheets, should be evaluated on the base of its effectiveness in addressing a given site, towards a nearly-zero energy path, as required by the current international standards [20,21,28].

Both issues are briefly discussed in the following.

\subsection{Effectiveness of the Proposed Actions}

The obtained results could seem not too encouraging in terms of energy savings. In fact, the reduction of the energy demand following the proposed actions accounts for about one third of the annual energy consumption for both the considered agritourisms. However, this is not surprising; the fact that the ARERA technical datasheets proposed interventions have been designed for the residential sector, in fact, place some limits on their application in a wider context, such as the agritourism one. Specifically, the limitations set on the reference physical units (UFRs) sizes might have made the outcomes much lower than the actually achievable results.

For instance, concerning datasheet 7 a maximum $k W_{p}$ of $20 \mathrm{~kW}$ is reductive for an agritourism, which could employ PV better having wide areas available to install such systems. Supporting this observation, during the survey of the agritourisms, it arose that both currently have a 100-kW PV undergoing design phase. In this context it would be more sensible to impose a limit on the maximum percentage of yearly energy consumption to be covered with the proposed intervention.

The latter consideration also applies to datasheet $8 \mathrm{~T}$.

Regarding, instead, datasheet $15 \mathrm{~T}$ the application problem is mainly related to the residential standard apartment size $\left(80-90 \mathrm{~m}^{2}\right)$, which is difficult to translate into an agritourism setting. In the conducted analysis, for instance, in order to comply with such a parameter, three to four rooms were grouped and assumed equal to 1.5 standard apartments, but it could be a questionable criterion.

As for datasheets 19T, it would be more reasonable to install a centralized system rather than considering the replacement of the single air conditioning units (the same goes for the heat pumps proposed by datasheets 15T).

Nevertheless, since one of the aims of this work was that of singling the most convenient EU Ecolabel "environmental actions packages", based on the comparison of the results reported in Tables 5 and 6 it was decided to tentatively choose three alternative options, both for Villa Dafne (VD-n) and $\operatorname{Bergi}(B-n)$, as follows:

- $\quad$ options $V D-1$ and $B-1$, constituted by datasheets number 5 and 7;

- options $V D-2$ and $B-2$, constituted by datasheets number $7,8 \mathrm{~T}$ and $(15 \mathrm{~T}+19 \mathrm{~T})$, the latter two must be considered together for the reasons indicated at the end of Section 2.4.2.;

- $\quad$ options VD-3 and B-3, constituted by datasheets number 7, $(15 \mathrm{~T}+19 \mathrm{~T})$ and $27 \mathrm{~T}$.

Table 7 summarizes the obtained results relative to the selected "environmental actions packages". By analyzing the data reported in Table 7 it was, therefore decided to consider as optimal options VD-2 for Villa Dafne and B-2 for Bergi. These two options allow, in fact, the obtaining of greater economic and energy savings and, correspondingly, higher $\mathrm{CO}_{2}$ emissions reductions. Moreover, they are characterized by the lower pay back periods.

It must be observed that the availability of effective and reliable methods for evaluating the energy actions involving agritourism is of paramount importance for suitable planning of this important sector. Therefore, the ARERA technical data sheets should be properly reconsidered in order to render them more complicit with the energy features of agritourism buildings and dwellings. 
Table 7. Summarized results for the two agritourisms.

\begin{tabular}{cccccccc}
\hline Agrit. & $\begin{array}{c}\text { Environm. } \\
\text { Actions } \\
\text { Package }\end{array}$ & $\begin{array}{c}\text { EU } \\
\text { Ecolabel } \\
\text { Points }\end{array}$ & $\begin{array}{c}\text { Environmental } \\
\text { Actions } \\
\text { Package Cost } \\
\mathbf{( \in )}\end{array}$ & $\begin{array}{c}\text { Energy } \\
\text { Savings } \\
(\text { AES) }\end{array}$ & $\begin{array}{c}\mathbf{C O}_{2} \\
\text { Emissions } \\
\text { Reduction } \\
\text { (tCO } \mathbf{2} \text { eq/Year) }\end{array}$ & $\begin{array}{c}\text { Economic } \\
\text { Savings } \\
\text { (E/Year) }\end{array}$ & $\begin{array}{c}\text { Pay Back } \\
\text { Period-Not } \\
\text { Discounted } \\
\text { (Years) }\end{array}$ \\
\hline Villa & $V D-1$ & 7.5 & $161,559.79$ & $24.46 \%$ & 26.3 & $10,884.84$ & 14.8 \\
Dafne & $V D-2$ & 10.5 & $149,008.01$ & $36.63 \%$ & 39.8 & $16,334.51$ & 9.1 \\
& $V D-3$ & 10 & $156,545.25$ & $34.43 \%$ & 37.6 & $15,364.20$ & 10.2 \\
\hline \multirow{3}{*}{ Bergi } & $B-1$ & 7.5 & $133,569.60$ & $29.05 \%$ & 21.3 & $9,404.42$ & 14.2 \\
& $B-2$ & 10.5 & $125,716.60$ & $42.64 \%$ & 31.5 & $15,416.72$ & 8.2 \\
& $B-3$ & 10 & $121,290.60$ & $37.64 \%$ & 27.7 & $12,726.73$ & 9.5 \\
\hline
\end{tabular}

\subsection{Towards a Nearly Zero Energy Agritourism}

As already mentioned, another intention of this work concerned the possibility of applying some actions to the agritourism structures, additional to those envisioned by the EU Ecolabel, in order to move towards a potential "nearly Zero Energy Agritourism (nZEA)". For this purpose, the results relative to ARERA datasheets 6 and 20T were added to the selected optimal options $V D-2$ and $B-2$ for Villa Dafne and Bergi, respectively; the outcomes of such combinations are reported in Figures 4 and 5.

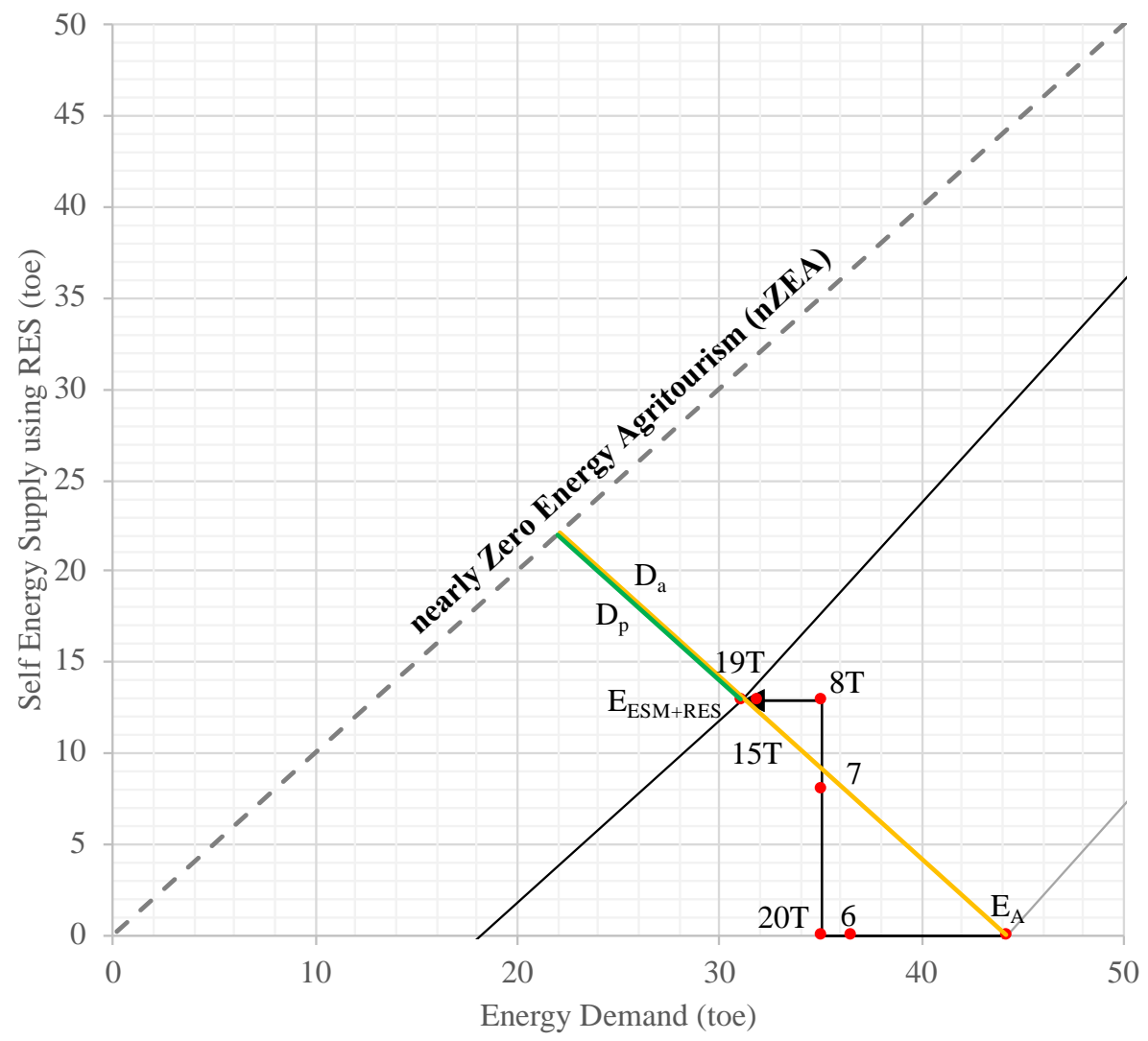

Figure 4. Path towards a nearly zero energy condition (nZEA) for Villa Dafne. 


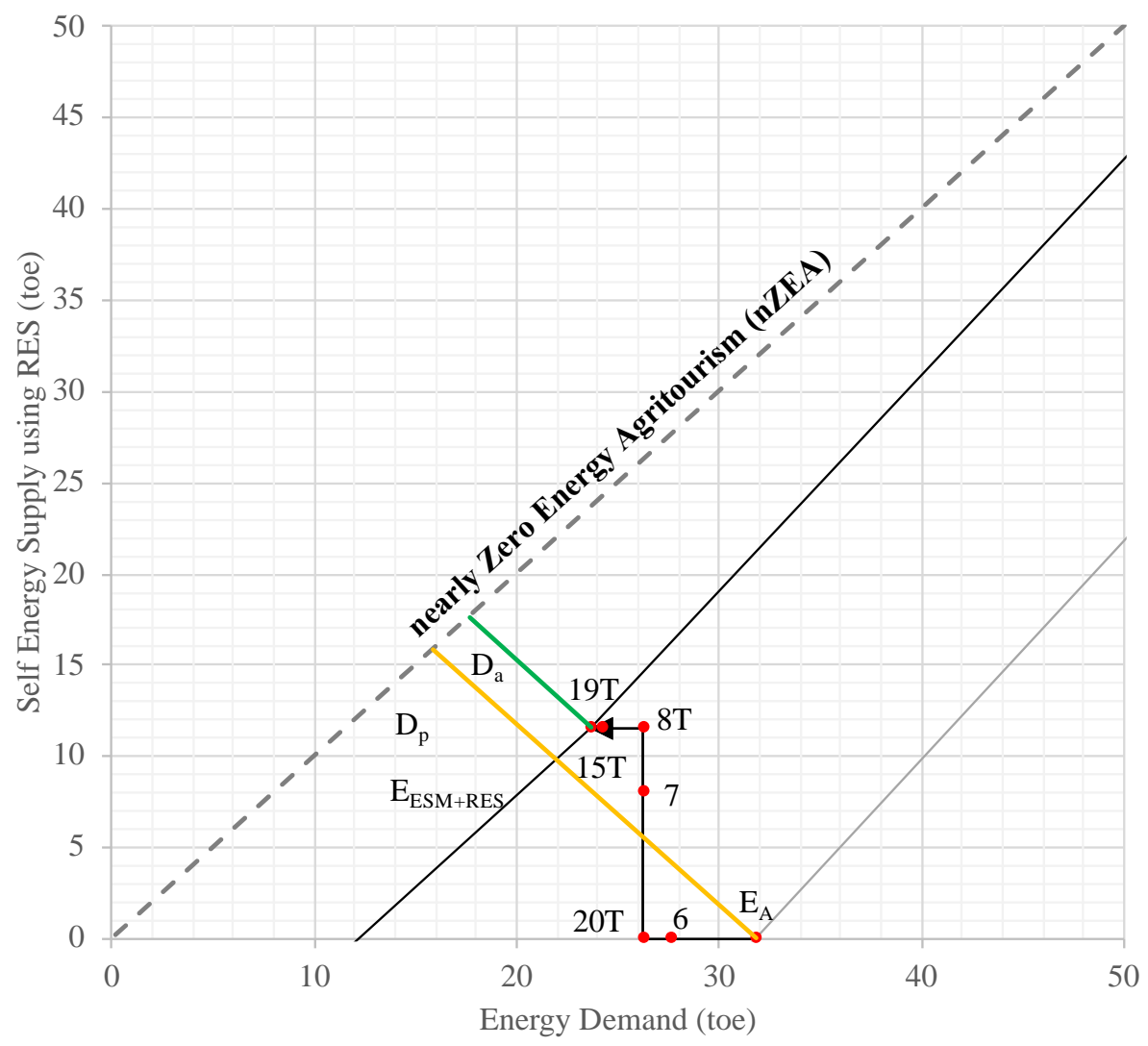

Figure 5. Path towards a nearly zero energy condition (nZEA) for Bergi.

According to such approaches and visual representations, already used in the literature [68-70], the nearly zero energy condition (nZEA) is reached when the energy demand (reported on the $\mathrm{x}$ axis) is completely covered by the self-energy supply from renewable sources (reported on the y axis).

Therefore, the effectiveness of the ARERA proposed interventions in moving agritourism towards a sustainable path, nZEA, is given as a simple summation of the effects provided by the energy saving measures- $\mathrm{E}_{\mathrm{ESM}}$ (datasheets 6, 15T, 19T, and 20T) and those attributable to the renewable energy sources- $\mathrm{E}_{\mathrm{RES}}$ (datasheets 7 and $8 \mathrm{~T}$ ). $\mathrm{E}_{\mathrm{A}}$ represents, instead, the current energy consumption and, $D_{a}$ and $D_{p}$ the current (ante operam) and achievable (post operam) minimum distances (hence the perpendicularity) from the nZEA condition, respectively.

For the sake of simplicity, this assumption does not take into account the synergetic effects that are likely induced by the contemporary adoption of different energy actions on a given agritourism site.

Consequently, the results reported in Figures 4 and 5 show that the selected combinations of interventions allow an improvement of 59\% for Villa Dafne and a $62 \%$ for Bergi, in terms of approaching the nZEA condition with respect to the current conditions.

Regardless of the obtained results, the proposed methodology can be seen as a simplified scheme for analyzing and ranking the "environmental actions packages" applicable to agritourisms, and could be usefully adopted by local administrations to define the impact of different scenarios in order to better define environmental policies concerning the agritourism sector.

The proposed assessment/estimation methodology could, therefore, also represent important information for the design of the rural tourism sector, and of the/a regional energy plan by stakeholders and decision makers [71,72].

\subsection{On the Correspondence between the EU Ecolabel Criteria and the ARERA Technical Datasheets}

The application of the ARERA technical datasheets and the EU Ecolabel criteria to two different agritourisms in Sicily (here considered representative of the whole regional agritourism context) enabled 
us to better understand the level of compliance between two such schemes. The level of correspondence cannot totally match, since the ARERA methodology has been designed specifically for residential buildings and, on the other hand, the EU Ecolabel for Tourist Accommodation Services applies expressly to tourism facilities, with features that could not be perfectly applicable to agritourisms. These latter, in fact, are generally characterized by the presence of cultivated soils and the production of agrifarm foods and products.

Nevertheless, the comparison exerted on the two sites has shown that some useful correspondences can be assessed. In fact, by means of the combination of the ARERA technical datasheets and the EU Ecolabel energy optional criteria, it is likely possible to identify some "environmental actions packages", suitable to the agritourism context. Such packages are allowed to obtain a 7.34 points minimum limit for the energy category, set by European regulation. In particular, it emerged that the combination of datasheets 5 and 7 (options $V D-1$ and B-1) allowed obtaining 7.5 EU Ecolabel points, while by adding datasheets $7,8 \mathrm{~T}$ and $15 \mathrm{~T}+19 \mathrm{~T}$ (options $V D-2$ and $B-2$ ) it is possible to achieve 10.5 points, and from the union of datasheets $7,15 \mathrm{~T}+19 \mathrm{~T}$, and $27 \mathrm{~T}$ (options $V D-3$ and B-3) a total of 10 points can be reached.

Therefore, a suitable implementation of the ARERA technical datasheets (that, apart from other things, permits an easy computation of the energy performances of various building and system components) is recommended to be ancillary utilized with the EU criteria in order to assess a unique scheme for the application of the EU Ecolabel brand.

In addition, the above verified correspondence, allowed us to introduce a criterion for ranking the effectiveness of the proposed measures within the framework of the nearly Zero Energy Buildings approach (nearly Zero Energy Agritourism, in this case). In other words, once the ARERA datasheets have provided useful energy saving results, achieved thanks to the implementation of the proposed interventions, it is easy to report such results in terms of closeness to a zero energy situation for a given agritourism.

\section{Conclusions}

Agritourisms represent an important reality in the Italian tourism sector, specifically in Sicily due to their numerical consistency and constantly growing trend. The idea at the base of the presented work stems from some considerations regarding the use of a simple method, based on the ARERA technical datasheets (which constitute an official Italian reference), to assess the energy, environmental, and economic benefits related to the implementation of some energy efficiency measures on a given agritourism, specifically aimed at achieving the EU Ecolabel environmental excellence brand, in the perspective of approaching a potential nearly Zero Energy condition.

The results of the conducted analysis put in evidence some discrepancies regarding the application of the ARERA calculation methods, devised for the residential sector, in a wider context, like that of agritourism. Such an outcome was foreseeable, but it has probably been highlighted even more by the fact that the datasheets results are outdated, having not been updated in the last few years.

Nevertheless, the adoption of the proposed efficiency interventions, despite not being specifically defined for the agritourism context, contributed in addressing both structures toward a nearly Zero Energy path, hence, improving their performances in terms of sustainability.

Apart from the interventions proposed by the ARERA, clearly agritourism sites can be interested in further renewable technologies in order to promote their energy sustainability. In fact, the application of solutions like micro wind turbines, biomass, and high efficiency cogeneration for such purposes has been demonstrated [73]. Similar and/or recently available technologies could represent a driver for implementing new ARERA technical datasheets, in order to render them more compliant with the agritourism context, and the EU targets for energy efficiency and emissions reductions in the civil sector.

In conclusion, it arose that, although it was possible to combine the ARERA technical datasheets with the EU Ecolabel criteria, in order to apply the proposed analysis methodology to the agritourism 
context in a more efficient way, the existing ARERA technical datasheets should be suitably updated and/or replaced by other more effective tools, expressly planned for the accommodation and catering business sector.

Author Contributions: All authors contributed equally to the design, experimental analyses and editing of this research. Conceptualization, L.C., M.L.G., G.P., G.R., G.S.; Data curation, L.C., M.L.G., G.P., G.R., G.S.; Methodology, L.C., M.L.G., G.P., G.R., G.S.; Writing—original draft, L.C., M.L.G., G.P., G.R., G.S.; Writing—review and editing, L.C., M.L.G., G.P., G.R., G.S. All authors have read and agreed to the published version of the manuscript.

Funding: This work was carried out within the research funds provided by the XXXIII Cycle Doctoral Course in Energy and Information Technologies of the University of Palermo.

Conflicts of Interest: The authors declare no conflict of interest.

\section{Appendix A}

Table A1. ARERA technical datasheets.

\begin{tabular}{|c|c|}
\hline Datasheet $\mathbf{N}^{\circ}$ & Proposed Action \\
\hline 1-tris & Installation of high-quality compact fluorescent lamps, not exceeding $15 \mathrm{~W}$ power \\
\hline 2 & $\begin{array}{c}\text { Replacement of electric water heater with gas water heater with sealed chamber } \\
\text { and piezoelectric ignition }\end{array}$ \\
\hline 3 & New installation of 4-star single-family efficiency boiler fueled with natural gas \\
\hline 4 & $\begin{array}{l}\text { Replacement of gas water heater (with open chamber and pilot flame) with gas } \\
\text { water heater (with sealed chamber and piezoelectric ignition) }\end{array}$ \\
\hline 5 & Replacement of simple glazing with double glazing \\
\hline 6 & Wall and roof insulation \\
\hline 7 & Use of photovoltaic systems with an electrical power of less than $20 \mathrm{~kW}$ \\
\hline $8 \mathrm{~T}$ & Installation of solar collectors for the production of domestic hot water \\
\hline 9T & $\begin{array}{l}\text { Installation of electronic frequency regulation systems (inverters) in electric motors } \\
\text { operating on pumping systems with power lower than } 22 \mathrm{~kW}\end{array}$ \\
\hline $10 \mathrm{~T}$ & Electricity recovery from natural gas decompression \\
\hline $11 \mathrm{~T}$ & Installation of engines with higher efficiency \\
\hline 13a-bis & $\begin{array}{l}\text { Installation, in residential environments, of water saving kits consisting of low-flow } \\
\text { aerators and low-flow shower heads }\end{array}$ \\
\hline 13b-bis & Installation of low flow shower dispensers in hotels and guest houses \\
\hline $13 c-b i s$ & Installation of low flow shower dispensers in sports facilities \\
\hline $15 \mathrm{~T}$ & $\begin{array}{l}\text { Installation of outdoor air electric heat pumps instead of boilers in newly built or } \\
\text { renovated residential buildings }\end{array}$ \\
\hline $16 \mathrm{~T}$ & $\begin{array}{l}\text { Installation of electronic frequency regulation systems (inverters) in electric motors } \\
\text { operating on pumping systems with power greater than or equal to } 22 \mathrm{~kW}\end{array}$ \\
\hline $17 \mathrm{~T}$ & $\begin{array}{l}\text { Installation of luminous flux regulators for mercury vapor lamps and high-pressure } \\
\text { sodium vapor lamps in outdoor lighting systems }\end{array}$ \\
\hline $18 \mathrm{~T}$ & $\begin{array}{l}\text { Replacement of mercury vapor lamps with high pressure sodium vapor lamps in } \\
\text { public lighting systems }\end{array}$ \\
\hline 19T & $\begin{array}{l}\text { Installation of high efficiency outdoor air conditioners with cooling capacity lower } \\
\text { than } 12 \mathrm{~kW}_{\mathrm{f}}\end{array}$ \\
\hline $20 \mathrm{~T}$ & $\begin{array}{c}\text { Thermal insulation of walls and roofs for summer cooling in domestic and } \\
\text { service sectors }\end{array}$ \\
\hline $21 \mathrm{~T}$ & $\begin{array}{l}\text { Application in the civil sector of small cogeneration systems for winter and summer } \\
\text { air-conditioning of rooms and the production of domestic hot water }\end{array}$ \\
\hline
\end{tabular}


Table A1. Cont.

\begin{tabular}{|c|c|}
\hline Datasheet $\mathbf{N}^{\circ}$ & Proposed Action \\
\hline $22 \mathrm{~T}$ & $\begin{array}{l}\text { Application in the civil sector of district heating systems for room air conditioning } \\
\text { and domestic hot water production }\end{array}$ \\
\hline $23 \mathrm{~T}$ & Replacement of incandescent traffic lights with LED traffic lights \\
\hline $24 \mathrm{~T}$ & Replacement of incandescent votive lamps with votive LED lamps \\
\hline $25 \mathrm{Ta}$ & $\begin{array}{l}\text { Installation of devices for automatically switching off equipment in standby mode } \\
\text { in the residential sector }\end{array}$ \\
\hline $25 \mathrm{~Tb}$ & $\begin{array}{l}\text { Installation of devices for automatically switching off equipment in stand-by mode } \\
\text { in the hotel sector }\end{array}$ \\
\hline $26 \mathrm{~T}$ & $\begin{array}{l}\text { Installation of centralized systems for winter and/or summer air conditioning in } \\
\text { civil use buildings }\end{array}$ \\
\hline $27 \mathrm{~T}$ & $\begin{array}{l}\text { Installation of electric heat pump for domestic hot water production in new and } \\
\text { existing plants }\end{array}$ \\
\hline $28 \mathrm{~T}$ & $\begin{array}{l}\text { Realization of high efficiency systems for the illumination of main motorway and } \\
\text { extra-urban tunnels }\end{array}$ \\
\hline $29 \mathrm{Ta}$ & $\begin{array}{l}\text { Implementation of new high-efficiency lighting systems for roads destined to } \\
\text { motorized traffic }\end{array}$ \\
\hline $29 \mathrm{~Tb}$ & $\begin{array}{c}\text { Installation of high efficiency lighting fixtures in existing lighting systems for roads } \\
\text { destined to motorized traffic }\end{array}$ \\
\hline
\end{tabular}

Table A2. EU Ecolabel for Tourist Accommodation Services criteria.

\begin{tabular}{|c|c|c|c|}
\hline & Mandatory & & Optional \\
\hline \multicolumn{4}{|c|}{ General management criteria } \\
\hline 1 & $\begin{array}{l}\text { Basis of an Environmental } \\
\text { Management System }\end{array}$ & 23 & $\begin{array}{l}\text { EMAS registration, ISO certification of the tourist } \\
\text { accommodation (up to } 5 \text { points) }\end{array}$ \\
\hline 2 & Staff training & 24 & $\begin{array}{l}\text { EMAS registration or ISO certification of suppliers } \\
\text { (up to } 5 \text { points) }\end{array}$ \\
\hline 3 & Information to guests & 25 & Ecolabelled services (up to 4 points) \\
\hline 4 & General maintenance & 26 & $\begin{array}{l}\text { Environmental and social communication and } \\
\text { education (up to } 2 \text { points) }\end{array}$ \\
\hline 5 & Consumption monitoring & 27 & $\begin{array}{l}\text { Consumption monitoring: Energy and water } \\
\text { sub-metering (up to } 2 \text { points) }\end{array}$ \\
\hline \multicolumn{4}{|c|}{ Energy criteria } \\
\hline 6 & $\begin{array}{l}\text { Energy efficient space heating } \\
\text { and water heating appliances }\end{array}$ & 28 & $\begin{array}{l}\text { Energy efficient space heating and water heating } \\
\text { appliances (up to } 3 \text { points) }\end{array}$ \\
\hline 7 & $\begin{array}{c}\text { Energy efficient air } \\
\text { conditioning and air-based } \\
\text { heat pumps appliances }\end{array}$ & 29 & $\begin{array}{l}\text { Energy efficient air conditioning and air-based heat } \\
\text { pumps appliances (up to } 3.5 \text { points) }\end{array}$ \\
\hline 8 & Energy efficient lighting & 30 & $\begin{array}{l}\text { Air-based heat pumps up to } 100 \mathrm{~kW} \text { heat output } \\
\text { (3 points) }\end{array}$ \\
\hline 9 & Thermoregulation & 31 & $\begin{array}{l}\text { Energy efficient household appliances and lighting } \\
\text { (up to } 4 \text { points) }\end{array}$ \\
\hline 10 & $\begin{array}{l}\text { Automatic switching off of } \\
\text { HVAC and lighting }\end{array}$ & 32 & Heat recovery (up to 3 points) \\
\hline
\end{tabular}


Table A2. Cont.

\begin{tabular}{|c|c|c|c|}
\hline \multicolumn{3}{|c|}{ Mandatory } & Optional \\
\hline 11 & $\begin{array}{l}\text { Outside heating and air } \\
\text { conditioning appliances }\end{array}$ & 33 & $\begin{array}{l}\text { Thermoregulation and window insulation (up to } \\
\qquad 4 \text { points) }\end{array}$ \\
\hline 12 & $\begin{array}{l}\text { Procurement of electricity } \\
\text { from a renewable } \\
\text { electricity supplier }\end{array}$ & 34 & $\begin{array}{l}\text { Automatic switch off appliances/devices (up to } \\
\qquad 4.5 \text { points) }\end{array}$ \\
\hline \multirow[t]{7}{*}{13} & Coal and heating oils & 35 & $\begin{array}{l}\text { District heating/cooling and cooling from } \\
\text { cogeneration (up to } 4 \text { points) }\end{array}$ \\
\hline & & 36 & Electric hand driers with proximity sensor (1 point) \\
\hline & & 37 & Space Heater emissions (1.5 points) \\
\hline & & 38 & $\begin{array}{l}\text { Procurement of electricity from a renewable } \\
\text { electricity supplier (up to } 4 \text { points) }\end{array}$ \\
\hline & & 39 & $\begin{array}{l}\text { On site self-generation of electricity through } \\
\text { renewable energy sources (up to } 5 \text { points) }\end{array}$ \\
\hline & & 40 & $\begin{array}{l}\text { Heating energy from renewable energy sources } \\
\text { (up to } 3.5 \text { points) }\end{array}$ \\
\hline & & 41 & Swimming pool heating (up to 1.5 points) \\
\hline \multicolumn{4}{|c|}{ Water criteria } \\
\hline 14 & $\begin{array}{l}\text { Efficient water fittings: } \\
\text { Bathroom taps and showers }\end{array}$ & 42 & $\begin{array}{l}\text { Efficient water fittings: Bathroom taps and showers } \\
\text { (up to } 4 \text { points) }\end{array}$ \\
\hline 15 & $\begin{array}{l}\text { Efficient water fittings: Toilets } \\
\text { and urinals }\end{array}$ & 43 & $\begin{array}{l}\text { Efficient water fittings: Toilets and urinals (up to } \\
4.5 \text { points) }\end{array}$ \\
\hline \multirow[t]{7}{*}{16} & $\begin{array}{l}\text { Reduction in laundry achieved } \\
\text { through reuse of towels and } \\
\text { bedclothes }\end{array}$ & 44 & Dishwasher water consumption (2.5 points) \\
\hline & & 45 & Washing machine water consumption (3 points) \\
\hline & & 46 & Indications on water hardness (up to 1.5 points) \\
\hline & & 47 & Optimised pool management (up to 2.5 points) \\
\hline & & 48 & Rainwater and grey water recycling (up to 3 points) \\
\hline & & 49 & Efficient irrigation (1.5 points) \\
\hline & & 50 & $\begin{array}{l}\text { Native or non-invasive alien species used in outdoor } \\
\text { planting (up to } 2 \text { points) }\end{array}$ \\
\hline \multicolumn{4}{|c|}{ Waste and wastewater criteria } \\
\hline 17 & $\begin{array}{l}\text { Waste prevention: Food } \\
\text { service waste reduction plan }\end{array}$ & 51 & Paper Products (up to 2 points) \\
\hline 18 & $\begin{array}{l}\text { Waste prevention: } \\
\text { Disposable items }\end{array}$ & 52 & Durable goods (up to 4 points) \\
\hline \multirow[t]{7}{*}{19} & $\begin{array}{l}\text { Waste sorting and sending } \\
\text { for recycling }\end{array}$ & 53 & Beverages provision (2 points) \\
\hline & & 54 & $\begin{array}{l}\text { Detergents and toiletries procurement (up to } \\
\qquad 2 \text { points) }\end{array}$ \\
\hline & & 55 & $\begin{array}{l}\text { Minimisation of the use of cleaning products } \\
\text { (1.5 point) }\end{array}$ \\
\hline & & 56 & De-icing (1 point) \\
\hline & & 57 & Used textiles and furniture (up to 2 points) \\
\hline & & 58 & Composting (up to 2 points) \\
\hline & & 59 & Waste water treatment (up to 3 points) \\
\hline
\end{tabular}


Table A2. Cont.

\begin{tabular}{cccc}
\hline & Mandatory & \multicolumn{2}{c}{ Optional } \\
\hline 20 & No smoking in common areas & 60 & No smoking in rooms (1 point) \\
\hline 21 & $\begin{array}{c}\text { Promotion of environmentally } \\
\text { preferable means of transport }\end{array}$ & 61 & Social policy (up to 2 points) \\
\hline 22 & $\begin{array}{c}\text { Information appearing on the } \\
\text { EU Ecolabel }\end{array}$ & 62 & Maintenance vehicles (1 point) \\
\hline & 63 & Environmentally preferable means of transport offer \\
(up to 2.5 points)
\end{tabular}

\section{Appendix B}

In the following the equations relating to the ARERA calculation procedures for each considered technical datasheet are given, in order to define the parameters reported in the following, Table A3.

Datasheet $\mathrm{N}^{\circ}$ 5, "Replacement of simple glazing with double glazing", allows obtaining the gross primary energy savings $(R L)$ achievable per individual building:

$$
R L=R S L \times S_{\text {window }}[\text { toe/ year/building }]
$$

where:

- $\quad R S L$ is the specific gross primary energy savings per $\mathrm{m}^{2}$ of replaced glass surface, dependent on the climatic zone and the buildings intended use (residential, office, school, hospital, etc.), expressed in toe/year $/ \mathrm{m}^{2}$;

- $\quad S_{\text {window }}$ is the replaced glass surface, expressed in $\mathrm{m}^{2}$.

Datasheet $\mathrm{N}^{\circ} 7$, "Use of photovoltaic systems with an electrical power of less than $20 \mathrm{~kW}$, allows obtaining the achievable specific gross primary energy savings $(R S L)$ for each reference physical unit $(U F R)$, represented by a photovoltaic system with electrical power $<20 \mathrm{~kW}$ :

$$
R S L=k W_{p} \times h_{e q} \times k_{1} \times 0.22 \cdot 10^{-3}[\text { toe } / \text { year }]
$$

where:

- $\quad k W_{p}$ is the peak power of the system, expressed in $\mathrm{kW}$;

- $\quad h_{e q}$ is a coefficient dependent on the solar belt of the considered province, expressed in h/year;

- $\quad k_{1}$ is a dimensionless coefficient that varies in function of the inclination $(\beta)$ of the photovoltaic modules on to the horizontal plane, that is $k_{1}=0.70$ for $\beta>70^{\circ}$, otherwise $k_{1}=1$;

Datasheet $\mathrm{N}^{\circ} 8 \mathrm{~T}$, "Installation of solar collectors for the production of domestic hot water", allows obtaining the annual shares of primary net energy savings $\left(R N_{C}\right)$ for each reference physical unit (UFR), represented by the opening surface $\left(\mathrm{m}^{2}\right)$ of the installed collectors:

$$
R N_{C}=R S N \times U F R[\text { toe } / \text { year }]
$$

where: 
- $\quad R S N$ is the net specific primary energy savings achievable per $\mathrm{m}^{2}$ of $U F R$, based on the system typology and on the solar belt to which the site belongs, expressed in toe/year $/ \mathrm{m}^{2}$;

Datasheet $\mathrm{N}^{\circ} 15 \mathrm{~T}$, “Installation of outdoor air electric heat pumps instead of boilers in newly built or renovated residential buildings", allows obtaining the annual shares of primary net energy savings $\left(R N_{C}\right)$ for each reference physical unit $(U F R)$, represented by a standard apartment, which in terms of square meters of heated surface corresponds to about $80-90 \mathrm{~m}^{2}$ :

$$
R N_{C}=a \times R S L \times U F R[\text { toe } / \text { year }]
$$

where:

- $\quad a$ is the additionality coefficient (dimensionless);

- $\quad R S L$ is the specific gross primary energy savings per single UFR, based on the COP of the heat pump typology, the surface/volume $(\mathrm{S} / \mathrm{V})$ ratio of the heated environment and the climatic zone (c.z.), expressed in toe $/$ year $/ \mathrm{m}^{2}$.

Datasheet $\mathrm{N}^{\circ} 19 \mathrm{~T}$, “Installation of high efficiency outdoor air conditioners with cooling capacity lower than $12 \mathrm{~kW}_{\mathrm{f}}$ ", allows obtaining the annual shares of primary net energy savings $\left(R N_{C}\right)$ for each reference physical unit (UFR), represented by $1 \mathrm{~kW}$ cooling capacity of the air conditioning system at nominal conditions (expressed in actual installed cooling capacity):

$$
R N_{C}=a \times R S L \times U F R[\text { toe } / \text { year }]
$$

where:

- $\quad a$ is the additionality coefficient (dimensionless);

- $\quad R S L$ is the specific gross primary energy savings per UFR, dependent on the solar belt of the considered province, expressed in toe $/$ year $/ \mathrm{m}^{2}$.

Datasheet $\mathrm{N}^{\circ} 27 \mathrm{~T}$, "Installation of electric heat pump for domestic hot water production in new and existing plants", allows obtaining the annual shares of primary net energy savings $\left(R N_{C}\right)$ for each reference physical unit (UFR), represented by an electric heat pump water heater for the production of domestic hot water (expressed in number of units):

$$
R N_{C}=a \times R S L \times U F R[\text { toe } / \text { year }]
$$

where:

- $\quad a$ is the additionality coefficient (dimensionless);

- $\quad R S L$ is the specific gross primary energy savings per single UFR, based on the COP of the heat pump typology and on the climatic zone, expressed in toe/year $/ \mathrm{m}^{2}$.

Datasheet $\mathrm{N}^{\circ} 6$, "Wall and roof insulation", allows obtaining the gross primary energy savings $(R L)$ achievable per insulated surface unit $\left(\mathrm{m}^{2}\right)$ :

$$
R L=R S L \times S_{\text {wall-roof }}[\text { toe/year/building }]
$$

where:

- $\quad R S L$ is the specific gross primary energy savings per $\mathrm{m}^{2}$ of insulated surface, dependent on the climatic zone and the building intended use (residential, office, school, hospital, etc.), expressed in toe/year $/ \mathrm{m}^{2}$;

- $\quad S_{\text {wall-roof }}$ is the insulated surface of walls and/or roof, expressed in $\mathrm{m}^{2}$. 
Datasheet $\mathrm{N}^{\circ} 20 \mathrm{~T}$, "Thermal insulation of walls and roofs for summer cooling in domestic and service sectors", allows obtaining the annual shares of primary net energy savings $\left(R N_{C}\right)$ achievable per $\mathrm{m}^{2}$ of insulated surface unit (UFR):

$$
R N_{C}=a \times R S L \times U F R[\text { toe } / \text { year }]
$$

where:

- $\quad a$ is the additionality coefficient (dimensionless);

- $\quad R S L$ is the specific gross primary energy savings per $\mathrm{m}^{2}$ of insulated surface, based on the thermal transmittance $K\left(\mathrm{~W} / \mathrm{m}^{2} / \mathrm{K}\right)$ of the structure (walls and/or) before the intervention, expressed in toe $/$ year $/ \mathrm{m}^{2}$.

Table A3. Equations (A1) to (A8) input data parameters for the two considered agritourisms.

\begin{tabular}{|c|c|c|c|c|}
\hline \multirow{2}{*}{$\begin{array}{l}\text { Data-Sheet } \\
\text { N. (Eq) }\end{array}$} & \multicolumn{2}{|l|}{ Villa Dafne } & \multicolumn{2}{|l|}{ Bergi } \\
\hline & Equation Input Data & Equation Result & Equation Input Data & Equation Result \\
\hline \multirow[b]{2}{*}{$5(1)$} & $\mathrm{RSL}=0.009$ toe $/$ year $/ \mathrm{m}^{2}$ & \multirow[b]{2}{*}{$\mathrm{RL}=2.7$ toe $/$ year } & $\mathrm{RSL}=0.005$ toe $/$ year $/ \mathrm{m}^{2}$ & \multirow[b]{2}{*}{$\mathrm{RL}=1.2$ toe/year } \\
\hline & $\mathrm{S}_{\text {window }}=305 \mathrm{~m}^{2}$ & & $\mathrm{~S}_{\text {window }}=236 \mathrm{~m}^{2}$ & \\
\hline \multirow{3}{*}{$7(2)$} & $\mathrm{kWp}=19.9 \mathrm{~kW}$ & \multirow{3}{*}{$\mathrm{RSL}=8.1$ toe $/$ year } & $\mathrm{kWp}=19.9 \mathrm{~kW}$ & \multirow{3}{*}{$\mathrm{RSL}=8.1$ toe $/$ year } \\
\hline & $\mathrm{h}_{\mathrm{eq}}=1852 \mathrm{~h} /$ year & & $\mathrm{h}_{\mathrm{eq}}=1852 \mathrm{~h} /$ year & \\
\hline & $\mathrm{k}_{1}=1$ & & $\mathrm{k}_{1}=1$ & \\
\hline \multirow{4}{*}{$8 \mathrm{~T}(3)$} & $\mathrm{RSN}_{\text {electrical }}=0.210$ toe $/$ year $/ \mathrm{m}^{2}$ & \multirow{4}{*}{$\mathrm{RN}_{\mathrm{C}}=4.9$ toe $/$ year } & $\mathrm{RSN}_{\text {electrical }}=0.210$ toe $/$ year $/ \mathrm{m}^{2}$ & \multirow{4}{*}{$\mathrm{RN}_{\mathrm{C}}=3.5$ toe/year } \\
\hline & $\mathrm{RSN}_{\text {gas }}=0.123$ toe $/$ year $/ \mathrm{m}^{2}$ & & $\mathrm{RSN}_{\text {gas }}=0.123$ toe $/$ year $/ \mathrm{m}^{2}$ & \\
\hline & $\mathrm{UFR}_{\text {electrical }}=23 \mathrm{~m}^{2}$ & & $\mathrm{UFR}_{\text {electrical }}=5 \mathrm{~m}^{2}$ & \\
\hline & $\mathrm{UFR}_{\text {gas }}=0$ & & $\mathrm{UFR}_{\mathrm{gas}}=21 \mathrm{~m}^{2}$ & \\
\hline \multirow{3}{*}{$15 \mathrm{~T}(4)$} & $a=1$ & \multirow{3}{*}{$\mathrm{RN}_{\mathrm{C}}=3.3$ toe $/$ year } & $a=1$ & \multirow{3}{*}{$\mathrm{RN}_{\mathrm{C}}=2.0$ toe $/$ year } \\
\hline & $\mathrm{RSL}=0.181$ toe/year $/ \mathrm{UFR}$ & & $\mathrm{RSL}=0.143$ toe $/$ year $/ \mathrm{UFR}$ & \\
\hline & $\mathrm{UFR}=18$ & & $\mathrm{UFR}=14$ & \\
\hline \multirow{3}{*}{$19 \mathrm{~T}(5)$} & $a=1$ & \multirow{3}{*}{$\mathrm{RN}_{\mathrm{C}}=0.7$ toe $/$ year } & $a=1$ & \multirow{3}{*}{$\mathrm{RN}_{\mathrm{C}}=0.6$ toe $/$ year } \\
\hline & $\mathrm{RSL}=0.0037$ toe $/$ year $/ \mathrm{UFR}$ & & RSL $=0.0037$ toe $/$ year $/$ UFR & \\
\hline & $\mathrm{UFR}=200 \mathrm{kWf}$ & & UFR = $150 \mathrm{kWf}$ & \\
\hline \multirow{3}{*}{$27 \mathrm{~T}(6)$} & $a=1$ & \multirow{3}{*}{$\mathrm{RN}_{\mathrm{C}}=3.9$ toe $/$ year } & $a=1$ & \multirow{3}{*}{$\mathrm{RN}_{\mathrm{C}}=1.9$ toe $/$ year } \\
\hline & RSL $=0.106$ toe/year/UFR & & RSL $=0.107$ toe/year/UFR & \\
\hline & $\mathrm{UFR}=37$ & & $\mathrm{UFR}=18$ & \\
\hline \multirow{2}{*}{$6(7)$} & $\mathrm{RSL}=0.0028$ toe $/$ year $/ \mathrm{m}^{2}$ & \multirow{2}{*}{$\mathrm{RL}=7.8$ toe $/$ year } & $\mathrm{RSL}=0.0015$ toe $/$ year $/ \mathrm{m}^{2}$ & \multirow{2}{*}{$\mathrm{RL}=4.2$ toe $/$ year } \\
\hline & $S_{\text {wall-roof }}=2768.5 \mathrm{~m}^{2}$ & & $S_{\text {wall-roof }}=2791.75 \mathrm{~m}^{2}$ & \\
\hline \multirow{3}{*}{$20 \mathrm{~T}(8)$} & $a=1$ & \multirow{3}{*}{$\mathrm{RN}_{\mathrm{C}}=1.4$ toe/year } & $a=1$ & \multirow{3}{*}{$\mathrm{RN}_{\mathrm{C}}=1.4$ toe $/$ year } \\
\hline & $\mathrm{RSL}=0.0005$ toe $/$ year $/ \mathrm{UFR}$ & & $\mathrm{RSL}=0.0005$ toe $/$ year/UFR & \\
\hline & $\mathrm{UFR}=2768.5 \mathrm{~m}^{2}$ & & $\mathrm{UFR}=2791.75 \mathrm{~m}^{2}$ & \\
\hline
\end{tabular}

\section{References}

1. UNWTO Annual Report 2017; United Nations World Tourism Organization: Badri, Spain, 2018.

2. $\quad$ WTTC Report 2017; World Travel and Tourism Council: London, UK, 2018.

3. Silva, F.B.; Herrera, M.A.M.; Rosina, K.; Barranco, R.R.; Freire, S.; Schiavina, M. Analysing spatiotemporal patterns of tourism in Europe at high-resolution with conventional and big data sources. Tour. Manag. 2018, 68, 101-115. [CrossRef]

4. Isik, C.; Dogan, E.; Ongan, S. Analyzing the Tourism-Energy-Growth Nexus for the Top 10 Most-Visited Countries. Economies 2017, 5, 40. [CrossRef]

5. Nižić, M.K.; Grdić, Z.Š.; Hustić, A. The Importance of Energy for the Tourism Sector. Acad. Tur. 2016, 9, 77-84. 
6. Tsemekidi-Tzeiranaki, S.; Bertoldi, P.; Labanca, N.; Castellazzi, L.; Serrenho, T.; Economidou, M.; Zangheri, P. Energy Consumption and Energy Efficiency Trends in the EU-28 for the Period 2000-2016; JRC Science for Policy Report; Joint Research Centre (JRC): Brussels, Belgium, 2018.

7. World Energy Balances 2018; International Energy Agency (IEA): Paris, France, 2018.

8. UNEP. Tourism Green Economy and Trade: Trends, Challenges and Opportunities; United Nations Environment Programme: Nairobi, Kenya, 2013; pp. 260-291.

9. Beccali, M.; Gennusa, M.L.; Coco, L.L.; Rizzo, G. An empirical approach for ranking environmental and energy saving measures in the hotel sector. Renew. Energy 2009, 34, 82-90. [CrossRef]

10. Pablo-Romero, M.P.; Sánchez-Braza, A.; Sánchez-Rivas, J. Relationships between Hotel and Restaurant Electricity Consumption and Tourism in 11 European Union Countries. Sustainability 2017, 9, 2109. [CrossRef]

11. Aissa, S.B.; Aissa, S.B.; Goaied, M.; Goaied, M. Determinants of tourism hotel market efficiency. Int. J. Cult. Tour. Hosp. Res. 2016, 10, 173-190. [CrossRef]

12. Paramati, S.R.; Shahbaz, M.; Alam, M.S. Does tourism degrade environmental quality? A comparative study of Eastern and Western European Union. Transp. Res. Part D Transp. Environ. 2017, 50, 1-13. [CrossRef]

13. Tang, C.; Zhong, L.; Jiang, Q. Energy efficiency and carbon efficiency of tourism industry in destination. Energy Effic. 2018, 11, 539-558. [CrossRef]

14. Paramati, S.R.; Alam, M.S.; Chen, C.F. The effects of tourism on economic growth and $\mathrm{CO}_{2}$ emissions: A comparison between developed and developing economies. J. Travel Res. 2017, 56, 712-724. [CrossRef]

15. Isik, C.; Kasımatı, E.; Ongan, S. Analyzing the causalities between economic growth, financial development, international trade, tourism expenditure and/on the $\mathrm{CO}_{2}$ emissions in Greece. Energy Sources Part B Econ. Plan. Policy 2017, 12, 665-673. [CrossRef]

16. Pan, S.Y.; Gao, M.; Kim, H.; Shah, K.J.; Pei, S.L.; Chiang, P.C. Advances and challenges in sustainable tourism toward a green economy. Sci. Total. Environ. 2018, 635, 452-469. [CrossRef] [PubMed]

17. United Nations. Transforming Our World: The 2030 Agenda for Sustainable Development; United Nations: New York, NY, USA, 2015.

18. Sustainable Development Goals. Available online: https://www.un.org/sustainabledevelopment/sustainabledevelopment-goals/ (accessed on 4 March 2020).

19. European Commission. Communication from the Commission Europe 2020. A Strategy for Smart, Sustainable and Inclusive Growth; European Commission: Brussels, Belgium, 2010.

20. European Commission. Communication from the Commission to the European Parliament, the Council, the European Economic and Social Committee and the Committee of the Regions. A Policy Framework for Climate and Energy in the Period from 2020 to 2030; European Commission: Brussels, Belgium, 2014.

21. European Commission. A Roadmap for Moving to a Competitive Low Carbon Economy in 2050; European Commission: Brussels, Belgium, 2011.

22. European Commission. Communication from the Commission to the European Parliament, the European Council, the Council, the European Economic and Social Committee, the Committee of the Regions and the European Investment Bank. A Clean Planet for All a European Strategic Long-Term Vision for a Prosperous, Modern, Competitive and Climate Neutral Economy; European Commission: Brussels, Belgium, 2018.

23. Ministero dello Sviluppo Economico; Ministero dell'Ambiente e della tutela del Territorio e del Mare. Italy's National Energy Strategy (2017); Ministero dello Sviluppo Economico: Rome, Italy; Ministero dell'Ambiente e della tutela del Territorio e del Mare: Rome, Italy, 2017.

24. UNWTO. A Roadmap for Celebrating Togerther; World Tourism Organization: Madrid, Spain, 2016.

25. Saarinen, J.; Rogerson, C.M. Tourism and the millennium development goals: Perspectives beyond 2015. Tour. Geogr. 2013, 16, 23-30. [CrossRef]

26. Styles, H.; Schönberger, J.L. European Commission JRC Scientific and Policy Report on Best Environmental Management Practice in the Tourism Sector D; Galvez Martos European Union: Brussels, Belgium, 2013.

27. Regulation (EC) No 1221/2009 of the European Parliament and of the Council of 25 November 2009 on the Voluntary Participation by Organisations in a Community Eco-Management and Audit Scheme (EMAS); Official Journal of the European Union, European Commission: Brussels, Belgium, 2009.

28. European Commission. Guide on EU Funding for the Tourism Sector 2014-2020; European Union: Brussels, Belgium, 2016; ISBN 978-92-79-58401-5.

29. Commission Decision (EU) 2017/175 of 25 January 2017 on Establishing EU Ecolabel Criteria for Tourist Accommodation; European Union, European Commission: Brussels, Belgium, 2017. 
30. González, J.P.; Yousif, C. Prioritising energy efficiency measures to achieve a zero net-energy hotel on the island of Gozo in the central Mediterranean. Energy Procedia 2015, 83, 50-59. [CrossRef]

31. Tsoutsos, T.; Tournaki, S.; De Santos, C.A.; Vercellotti, R. Nearly Zero Energy Buildings Application in Mediterranean hotels. Energy Procedia 2013, 42, 230-238. [CrossRef]

32. Buso, T.; Becchio, C.; Corgnati, S.P. NZEB, cost- and comfort-optimal retrofit solutions for an Italian Reference Hotel. Energy Procedia 2017, 140, 217-230. [CrossRef]

33. Parpairi, K. Sustainability and Energy Use in Small Scale Greek Hotels: Energy Saving Strategies and Environmental Policies. Procedia Environ. Sci. 2017, 38, 169-177. [CrossRef]

34. Bianco, V.; Scarpa, F.; Tagliafico, L.A. Modeling energy consumption and efficiency measures in the Italian hotel sector. Energy Build. 2017, 149, 329-338. [CrossRef]

35. Datatur Report 2018. Available online: http://www.federalberghi.it/rapporti/rapporti.aspx?IDEL=160\# .WCM66S3hDIU (accessed on 4 March 2020).

36. Eurostat Report 2018. Available online: http://ec.europa.eu/eurostat/web/tourism/data/database (accessed on 4 March 2020).

37. ISTAT Report 2018, Tourist flow in Italy Year 2017. Available online: https://www.istat.it/it/files//2018/11/EN_ Tourism_2017.pdf (accessed on 4 March 2020).

38. ONT Report 2019. Turismo in Cifre 2018/2019 (ONT, Italian National Tourism Observatory, Elaboration on WTTC, World Travel \& Tourism Council Data); Agenzia Nazionale Turismo Italia, Ufficio Studi ENIT: Rome, Italy, 2019.

39. Turismo in Cifre. Available online: http://www.ontit.it/opencms/export/sites/default/ont/it/documenti/files/ ONT_2019-07-30_03066.pdf (accessed on 4 March 2020).

40. Ali, Y.; Ciaschini, M.; Pretaroli, R.; Severini, F.; Socci, C. Economic Relevance of Tourism Industry: The Italian Case; Quaderno di Dipartimento n. 72 Università degli Studi di Macerata, Dipartimento di Economia e Diritto: Roma, Italy, 2014.

41. ISPRA Report 2018. Available online: https://annuario.isprambiente.it/ada/macro/28 (accessed on 4 March 2020).

42. Green Key. Available online: https://www.greenkey.global (accessed on 4 March 2020).

43. Bandiera Blu. Available online: http://www.bandierablu.org/common/blueflag.asp?anno=2019\&tipo=bb (accessed on 4 March 2020).

44. Spighe Verdi. Available online: http://www.spigheverdi.net/il-programma/ (accessed on 4 March 2020).

45. Fee-Italia. Available online: http://www.feeitalia.org/fee/index.aspx (accessed on 4 March 2020).

46. Ministero delle Politiche Agricole Alimentari Forestali e del Turismo. Available online: https://www. politicheagricole.it/flex/cm/pages/ServeBLOB.php/L/IT/IDPagina/202 (accessed on 4 March 2020).

47. D'Alessandro, F. Green Building for a Green Tourism. A New Model of Eco-Friendly Agritourism. Agric. Agric. Sci. Procedia 2016, 8, 201-210. [CrossRef]

48. ISTAT Report 26 settembre 2018, “Anno 2017-LE AZIENDE AGRITURISTICHE IN ITALIA”. Available online: https://www.istat.it/it/files//2018/09/ReportAGR_2017.pdf (accessed on 4 March 2020).

49. Mastronardi, L.; Giaccio, V.; Giannelli, A.; Scardera, A. Primi risultati di un'analisi aziendale, Agriregionieuropa. Agritur. Sostenibilità Ambient. anno $11 n^{\circ} 402015$.

50. Peri, G.; Sanyé-Mengual, E.; Rieradevall, J.; Ciulla, G.; Rizzo, G. Proposal of a New Operative Brand for Environmentally Labelling Agritourism: Embodying Tourism, Buildings and Transportation Requirements. World Appl. Sci. J. 2014, 32, 1764-1774.

51. Peri, G.; Rizzo, G. The overall classification of residential buildings: Possible role of tourist EU Ecolabel award scheme. Build. Environ. 2012, 56, 151-161. [CrossRef]

52. Technical Datasheets ARERA-Autorità di Regolazione per Energia Reti e Ambiente. Available online: https://www.arera.it/it/ (accessed on 4 March 2020).

53. P.S.R Sicilia 2014-2020_Programma di Sviluppo Rurale—Regione Sicilia; Regione Siciliana: Sicily, Italy, 2013.

54. Disciplina dell'agriturismo. Gazz. Uff. 16 marzo 2006, n. 632006.

55. Regione Sicilia—Legge Regionale. Norme Sull'Agriturismo; Regione Siciliana: Sicily, Italy, 1997.

56. Disciplina dell'agriturismo in Sicilia. Gazz. Uff. Reg. Sicil. 1 Mar 2010 Parte I 2010.

57. LEGGE. Norme per la Concorrenza e la Regolazione dei Servizi di Pubblica Utilità. Istituzione delle Autorità di Regolazione dei Servizi di Pubblica Utilità. GU Serie Generale n.270 del 18-11-1995 - Suppl. Ordinario n. 136. 1995. Available online: https://www.federalismi.it/nv14/articolo-documento.cfm?Artid=26481 (accessed on 4 March 2020). 
58. Legge. Recante Disposizioni Urgenti per la Crescita, L'equità e il Consolidamento dei Conti Pubblici. GU Serie Generale n.284 del 06-12-2011 - Suppl. Ordinario n. 251. 2011. Available online: http://www.senato.it/service/ PDF/PDFServer/BGT/00737571.pdf (accessed on 4 March 2020).

59. Decreto Legislativo. Attuazione della Direttiva 2012/27/UE Sull'Efficienza Energetica, che Modifica le Direttive 2009/125/CE e 2010/30/UE e Abroga le Direttive 2004/8/CE e 2006/32/CE. GU Serie Generale n.165 del 18-07-2014. 2014. Available online: http://documenti.camera.it/leg17/dossier/pdf/AP0020.pdf (accessed on 4 March 2020).

60. LEGGE. Bilancio di Previsione dello Stato per L'anno Finanziario 2018 e Bilancio Pluriennale per il Triennio 2018-2020. GU Serie Generale n.302 del 29-12-2017 - Suppl. Ordinario n. 62. 2017. Available online: https://www.tuttoambiente.it/leggi/bilancio-2018/ (accessed on 4 March 2020).

61. Council Regulation (EEC) No 880/92 of 23 March 1992 on a Community Eco-Label Award Scheme; European Commission: Brussels, Belgium, 1992.

62. Regulation (Ec) No 66/2010 of the European Parliament and of the Council of 25 November 2009 on the EU Ecolabel; European Commission: Brussels, Belgium, 2010.

63. EU Ecolabel. Available online: https://ec.europa.eu/environment/ecolabel/ (accessed on 4 March 2020).

64. Ecolabel UE. Available online: http://certificazioni.isprambiente.it/valcer/node/3 (accessed on 4 March 2020).

65. Moro, A.; Lonza, L. Electricity carbon instensity in European Member States: Impacts on GHG emissions of electric vehicles. Transp. Res. Part D 2018, 64, 5-14. [CrossRef]

66. Vandepaer, L.; Treyer, K.; Mutel, C.; Bauer, C.; Amor, B. The integration of long-term marginal electricity supply mixes in the ecoinvent consequential database version 3.4 and examination of modeling choices. Int. J. Life Cycle Assess. 2019, 24, 1409-1428. [CrossRef]

67. ISPRA Rapporti 317/2020, Fattori di Emissione Atmosferica di Gas a Effetto Serra nel Settore Elettrico Nazionale e nei Principali Paesi Europei; ISPRA: Roma, Italy, 2020; ISBN 978-88-448-0992-8.

68. Supplemento ordinario alla GAZZETTA UFFICIALE DELLA REGIONE SICILIANA (p. I) n. 5 del 1 febbraio 2019 (n. 8)-Prezzario unico regionale per i lavori pubblici anno 2019. Available online: http://www.gurs.regione.sicilia.it/Gazzette/g19-05o/g19-05o.pdf (accessed on 4 March 2020).

69. Guerrieri, M.; Gennusa, M.L.; Peri, G.; Rizzo, G.; Scaccianoce, G. University campuses as small-scale models of cities: Quantitative assessment of a low carbon transition path. Renew. Sustain. Energy Rev. 2019, 113, 109263. [CrossRef]

70. Yoshida, Y.; Shimoda, Y.; Ohashi, T. Strategies for a sustainable campus in Osaka University. Energ. Build. 2017, 147, 1-8. [CrossRef]

71. Bisegna, F.; Cirrincione, L.; Maini, B.L.C.; Peri, G.; Rizzo, G.; Scaccianoce, G.; Sorrentino, G. Fostering the energy efficiency through the energy savings: The case of the University of Palermo. In Proceedings of the 2019 IEEE International Conference on Environment and Electrical Engineering and 2019 IEEE Industrial and Commercial Power Systems Europe, Palermo, Italy, 11-14 June 2019.

72. Giaccone, A.; Lascari, G.; Peri, G.; Rizzo, G. An ex post criticism, based on stakeholders' preferences, of a residential sector's energy master plan: The case study of the Sicilian region. Energy Effic. 2017, 10, 129-149. [CrossRef]

73. Vourdoubas, J. The Nexus between Agriculture and Renewable Energy Sources in the Island of Crete, Greece. Eur. J. Appl. Sci. 2020, 8, 101-110.

(C) 2020 by the authors. Licensee MDPI, Basel, Switzerland. This article is an open access article distributed under the terms and conditions of the Creative Commons Attribution (CC BY) license (http://creativecommons.org/licenses/by/4.0/). 